\title{
Mitochondrial Import Receptor Subunit TOM20 Homolog
}

National Cancer Institute

\section{Source}

National Cancer Institute. Mitochondrial Import Receptor Subunit TOM20 Homolog. NCI

Thesaurus. Code C118209.

Mitochondrial import receptor subunit TOM20 homolog (145 aa, 16 kDa) is encoded by the human TOMM20 gene. This protein plays a role in mitochondrial protein localization. 